Crop Breeding and Applied Biotechnology 13: 221-227 2013

Brazilian Society of Plant Breeding. Printed in Brazil

\title{
ARTICLE
}

\section{Molecular diversity in Coffea canephora germplasm conserved and cultivated in Brazil}

Flávio de França Souza ${ }^{1}$, Eveline Teixeira Caixeta ${ }^{2}$, Luís Felipe Ventorim Ferrão ${ }^{3}$, Guilherme Ferreira Pena ${ }^{4}$, Ney Sussumu Sakiyama ${ }^{5}$, Eunize Maciel Zambolim ${ }^{5}$, Laércio Zambolim ${ }^{5}$ and Cosme Damião Cruz ${ }^{5}$

Received 02 August 2013

Accepted 06 September 2013

\begin{abstract}
This work aimed to characterize accessions that represent the C. canephora germplasm conserved and cultivated in Brazil. A total of 130 accessions from germplasm banks of IAC (São Paulo), UFV (Minas Gerais) and also collected in plantations of the State of Espirito Santo and Rondonia were evaluated with a set of 20 new microsatellite primers. Multivariate methods were used to estimate the relationship among the accessions. High level of polymorphism and two major diversity clusters were identified. First cluster was composed by the accessions conserved in the IAC and UFV collections and the second was formed by accessions collected in areas under cultivation. Accessions from Espírito Santo and Rondonia were clear separated, composing two subclusters. Despite the great polymorphism found in Brazilian plantations, the diversity may be increased, because a new threshold in the genetic gains is expected on breeding programs with the intensification of the use of conserved germplasm.
\end{abstract}

Key words: Robusta coffee, genetic diversity, microsatellite marker.

\section{INTRODUCTION}

Coffea canephora Pierre ex. Froehner presents a wide genetic variability, with one of the widest geographic natural distribution within the subgenus Coffea (Maurin et al. 2007). Likewise most diploid species in genus Coffea, C. canephora is allogamous and presents a self-incompatibility system.

Brazil is the second largest producer of $C$. canephora, producing about $25 \%$ of the world yield (USDA 2012). The States of Espírito Santo and Rondônia are responsible for over $75 \%$ of the production (CONAB 2013). In that country, main C. canephora germplasm collections are placed in governmental institutions, where breeding programs are developed, i.e.: Instituto Agronômico de Campinas (IAC), in São Paulo; Universidade Federal de Viçosa (UFV), in Minas Gerais; Instituto Capixaba de Pesquisa, Assistência Técnica e Extensão Rural (Incaper), in Espírito Santo and Embrapa (Embrapa Rondônia), in Rondônia. The germplasm conserved in IAC and UFV are mainly composed by accessions introduced from Africa, after FAO expeditions in that continent during the last century (Silvestrini et al.
2008, Fazuoli et al. 2009). On the other hand, Incaper and Embrapa Rondônia have collected a great amount of accessions in plantations from their respective states (Ferrão et al. 2007a, Souza and Santos 2009). As a consequence, those four institutions harbor a representative sample of the germplasm conserved or grown in that country.

Brazilian C. canephora accessions were studied using phenotypic traits (Fonseca et al. 2006, Ivoglo et al. 2008, Souza and Santos 2009) and RAPD markers (Ferrão et al. 2007b, Silvestrini et al. 2008). Those studies have confirmed that there is a wide variability within the germplasm maintained in the Brazilian collections. However, despite the advantages of microsatellites - e.g.: high reproducibility, multi-allelic locus, co-dominant inheritance, high degree of polymorphism, relative abundance and good coverage of the genome (Powell et al. 1996) - there are a few works using these markers to investigate $C$. canephora diversity. Furthermore, there is no report of comparisons about the diversity among accessions from different institutions, providing a well representative coverage of this germplasm.

\footnotetext{
${ }^{1}$ Embrapa Semiárido, 56.302-970, Petrolina, PE, Brazil

${ }^{2}$ Embrapa Café, Universidade Federal de Viçosa (UFV), 36.570-000, Viçosa, MG, Brazil. *E-mail: eveline.caixeta@embrapa.br

${ }^{3}$ Escola Superior de Agricultura "Luiz de Queiroz",13.418-900, Piracicaba, SP, Brazil

${ }^{4}$ Universidade Estadual do Norte Fluminense Darcy Ribeiro (UENF), 28.013-600, Campos dos Goytacazes, RJ, Brazil

${ }^{5} \mathrm{UFV}$
} 
Thus, this study aimed to characterize accessions representing the germplasm cultivated in Brazilian plantations and conserved in research institutions, in order to propose guide lines to management of gene banks and breeding strategies.

\section{MATERIAL AND METHODS}

\section{Plant material}

A total of 130 accessions of C. canephora (Table 1) were genotyped. These accessions comprise a good sample of the germplasm used in the Brazilian breeding programs. Forty three accessions were obtained from IAC (18 belonging to varietal group Kouillou and 25 to varietal group Robusta) and 11 accessions were obtained from UFV. The other accessions were collected by Incaper and Embrapa in traditional coffee producing areas at Espírito Santo (40 accessions) and Rondônia (36 accessions). Accessions of C. arabica and Híbrido de Timor (C. arabica x C. canephora) were included in the analysis as out group species.

\section{DNA extraction}

Young and completely extended leaves were collected from each accession, frozen at $-80^{\circ} \mathrm{C}$, lyophilized, ground to become a fine powder and kept at $-20{ }^{\circ} \mathrm{C}$ until used. Genomic DNA was extracted using the method described by Diniz et al. (2005) and all DNA samples were prepared to a final concentration of $25 \eta \mathrm{g} \mu \mathrm{L}-{ }^{1}$.

\section{Microsatellite markers}

Twenty new microsatellites were used in this study. These DNA markers were developed from non-redundant Express Sequence Tags (EST) of the Brazilian Coffee Genome Project (Table 2), in Coffee Biotechnology Lab (BIOCAFE - UFV).

Each reaction was set to a final volume of $20 \mu \mathrm{L}$, containing $50 \eta \mathrm{g}$ of genomic DNA, 0.6 unit of Taq DNA polymerase, Taq buffer $1 \mathrm{x}, 1 \mathrm{mM}$ of $\mathrm{MgCl}_{2}, 150 \mu \mathrm{M}$ of each dNTP and $0.1 \mu \mathrm{M}$ of each primer. PCR amplifications were carried out using touchdown proceeding, which comprises initial denaturation at $94^{\circ} \mathrm{C}$ for $2 \mathrm{~min}$, followed by 10 cycles of denaturation at $94{ }^{\circ} \mathrm{C}$ for $0.5 \mathrm{~min}$, annealing at $67^{\circ} \mathrm{C}$ for $0.5 \mathrm{~min}$, decreasing $1{ }^{\circ} \mathrm{C}$ after each cycle, and extension at $72{ }^{\circ} \mathrm{C}$ for $0.5 \mathrm{~min}$. After that, another set of 30 cycles, comprising denaturation at $94{ }^{\circ} \mathrm{C}$ for $0.5 \mathrm{~min}$, annealing at $55^{\circ} \mathrm{C}$ for $0.5 \mathrm{~min}$ and extension at $72{ }^{\circ} \mathrm{C}$ for $0.5 \mathrm{~min}$, was accomplished followed by a final 8 min extension time at $72^{\circ} \mathrm{C}$. Before electrophoresis, $\mathrm{PCR}$ products were denatured in $8 \mu \mathrm{L}$ of denaturing dye ( $95 \%$ formamide) at $94{ }^{\circ} \mathrm{C}$ for 5 min and $7 \mu \mathrm{L}$ of sample were loaded on a standard $6 \%$ polyacrylamide gel at $50{ }^{\circ} \mathrm{C}$ and run at a constant power of $90 \mathrm{~W}$ for about $2 \mathrm{~h}$. Post-PCR multiplex, which involved the multi-loading of individual PCR assays (two to four SSRs per running), was performed spacing successive loads by 10 to $30 \mathrm{~min}$ during electrophoresis, depending on the prior information about fragment size. At last, the gel was treated with ethanol $(10 \%)+$ acetic acid (1\%), followed by nitric acid (1,5\%); stained with silver nitrate (4\%), developed with sodium carbonate $(3 \%)$ and formaldehyde $(0.03 \%)$; and fixed with acetic acid (5\%) and dried for posterior analysis at a transilluminator apparatus.

\section{Data analysis}

The evaluation of each locus was performed considering homozygotes and heterozygotes, individuals which showed one or two alleles, respectively. The dissimilarity between the accessions was estimated based on the complement ( $1-S_{\mathrm{ii}}$ ) of the weighted coincidence index, using the equation: $S_{i^{\prime}}=\frac{1}{2} \sum_{j=1}^{L} p_{j} c_{j}$, where $S_{\mathrm{ii}}$ is the similarity between the accessions $i$ and $i^{\prime} ; L$ is the total number of loci; $c_{j}$ is the number of common alleles between $i$ and $i$; and $p_{j}$ is the weight associated to $j$ locus, obtained by $a /$ A, being $a_{i}$, the number of alleles in locus $j$ and A total number of alleles. Principal Coordinate Analysis (PCoA) was performed to view the overall diversity. The dissimilarity matrix was also represented in a dendrogram based on the unweighted pair-group method using arithmetic averages (UPGMA) to establish genetic relations among accessions. Goodnessof-fit of the tree was tested comparing cophenetic value matrix, with the original dissimilarity matrix. Statistical procedures were accomplished using the software packages: Genes (Cruz 2001), Darwin 5.0 (Perrier et al. 2003) and NTSYS-pc (Rohlf 1998).

\section{RESULTS AND DISCUSSION}

Genetic relationships among the 130 accessions of $C$. canephora and others species of the genus Coffea were evaluated with UPGMA clustering technique (Figure 1). The cophenetic correlation was high $(81.5 \%)$, and the levels of stress and distortion were low ( $1.4 \%$ and $11.8 \%$, respectively), demonstrating that the dendrogram satisfactorily represents the original matrix of dissimilarities. C. arabica and Híbrido de Timor, as expected, composed an out group, confirming the efficacy of the new microsatellites to distinguish different species in genus Coffea. Accessions of germplasm collections and those sampled in plantations formed distinct cluster, but no logical subdivisions were observed inside each one. IAC and UFV accessions appeared merged on upper cluster and Rondônia and Espírito Santo accessions were also mixed in lower cluster.

The overall diversity among the 130 accessions of $C$. canephora was also represented in the bi-dimensional 
Table 1. List of Coffea sp accessions genotyped in this study

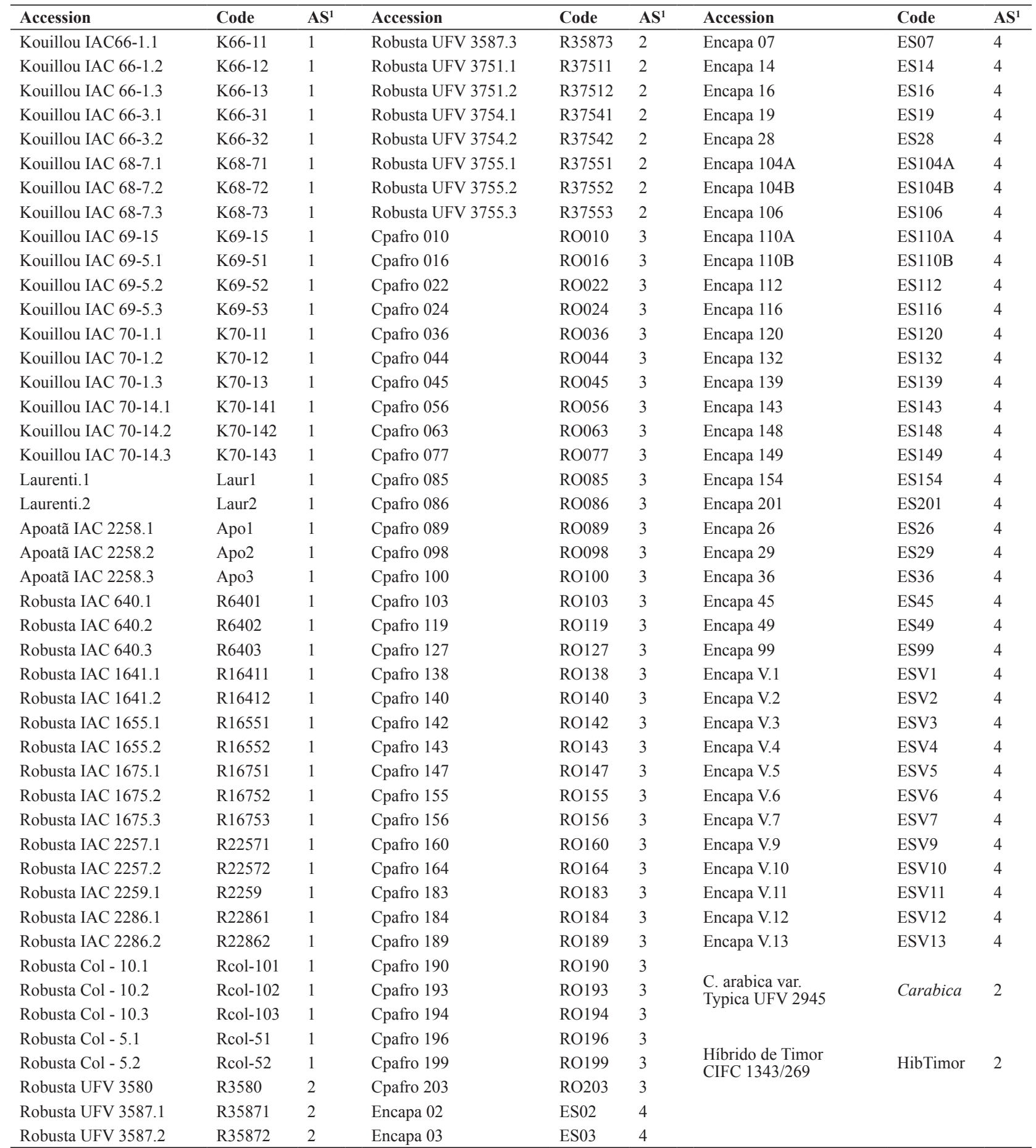

${ }^{1}$ Accession source: 1) Coffee Germplasm Collection of Instituto Agronômico de Campinas (IAC), São Paulo; 2) Coffee Germplasm Collection of Universidade Federal de Viçosa (UFV), Minas Gerais; 3) Accessions collected in commercial coffee fields in Rondônia State, by Embrapa, and 4) in Espírito Santo State by the Instituto Capixaba de Assistência Técnica, Pesquisa e Extensão Rural (INCAPER). 
FF Souza et al.

Table 2. Identification, sequences of forward and reverse primer, temperature of melt and allele size for 28 microsatellites from Coffea canephora

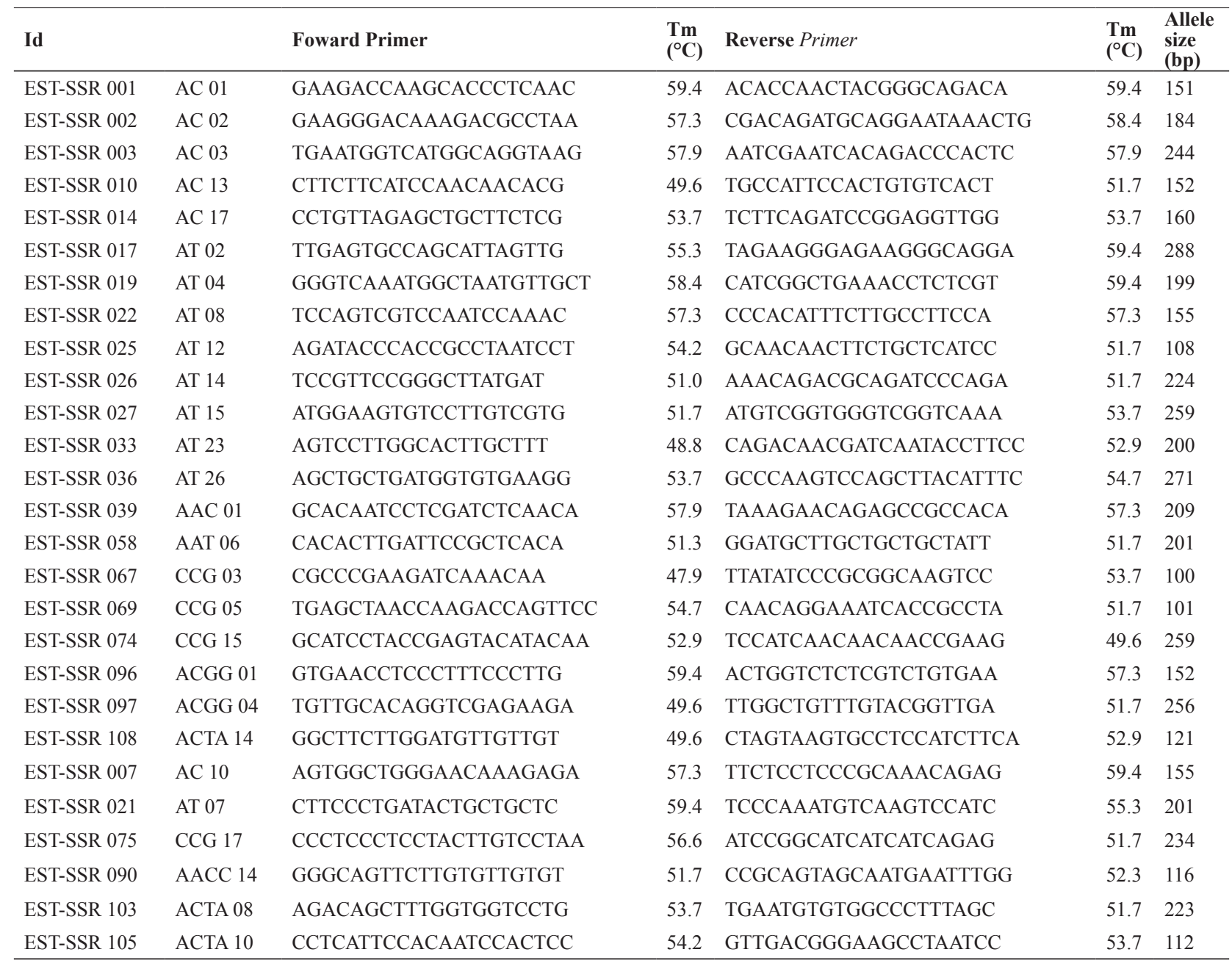

graphics based on the principal coordinate analysis (Figure 2). The result corroborated the previous clustering observed by UPGMA, but a better layout of that diversity was found. In the graphic, first, second and third axis exhibited, respectively, $19.1 \%, 5.8 \%$ and $3.3 \%$ of the total variability. Accessions were clearly separated in two major groups, in accordance their origin, i.e.: 1) accessions preserved in germplasm banks and 2) accessions collected in Brazilian plantations. Cultivated accessions were plotted at the left side of the plan, composed by the $1^{\text {st }}$ and $2^{\text {nd }}$ coordinates. A division by location was also observed in this cluster. Accessions from Rondônia and Espírito Santo occupied upper and lower halves of the plan, respectively. Nevertheless, some misclassifications were observed, i.e.: five accessions of Rondônia (RO098, RO189, RO143, RO100 and RO063) were positioned in the Espírito Santo cluster and two accessions of Espírito Santo were included in Rondônia cluster (ES02 and ES03). Accessions from UFV collection and the
Robustas from IAC were positioned in the lower right side of the plan and no remarkable sub-clustering was observed. This similarity among them may indicate that UFV accessions also belong to the Robusta varietal group. Kouillou accessions from IAC occupied a slightly upper position in right side of the plan. In the graphic, composed by $1^{\text {st }}$ and $3^{\text {rd }}$ coordinates, accessions of preserved and cultivated accessions continued apart, reinforcing their genetic distance.

In Brazil, the cultivated plants of C. canephora are generically called 'Conilon', what it supposed to be a linguistic derivation of Kouillou. Nevertheless, is necessary to mention that the word 'Kouillou' was historically defined according to solely morphological criteria and may represent different populations in many countries as Ivory Coast, Benin, Gabon (Montagnon et al. 1998). Notably, only six accessions from Rondônia (RO056, RO190, RO193, RO194 and RO199) and one from Espírito Santo (ESV.3) were grouped among 


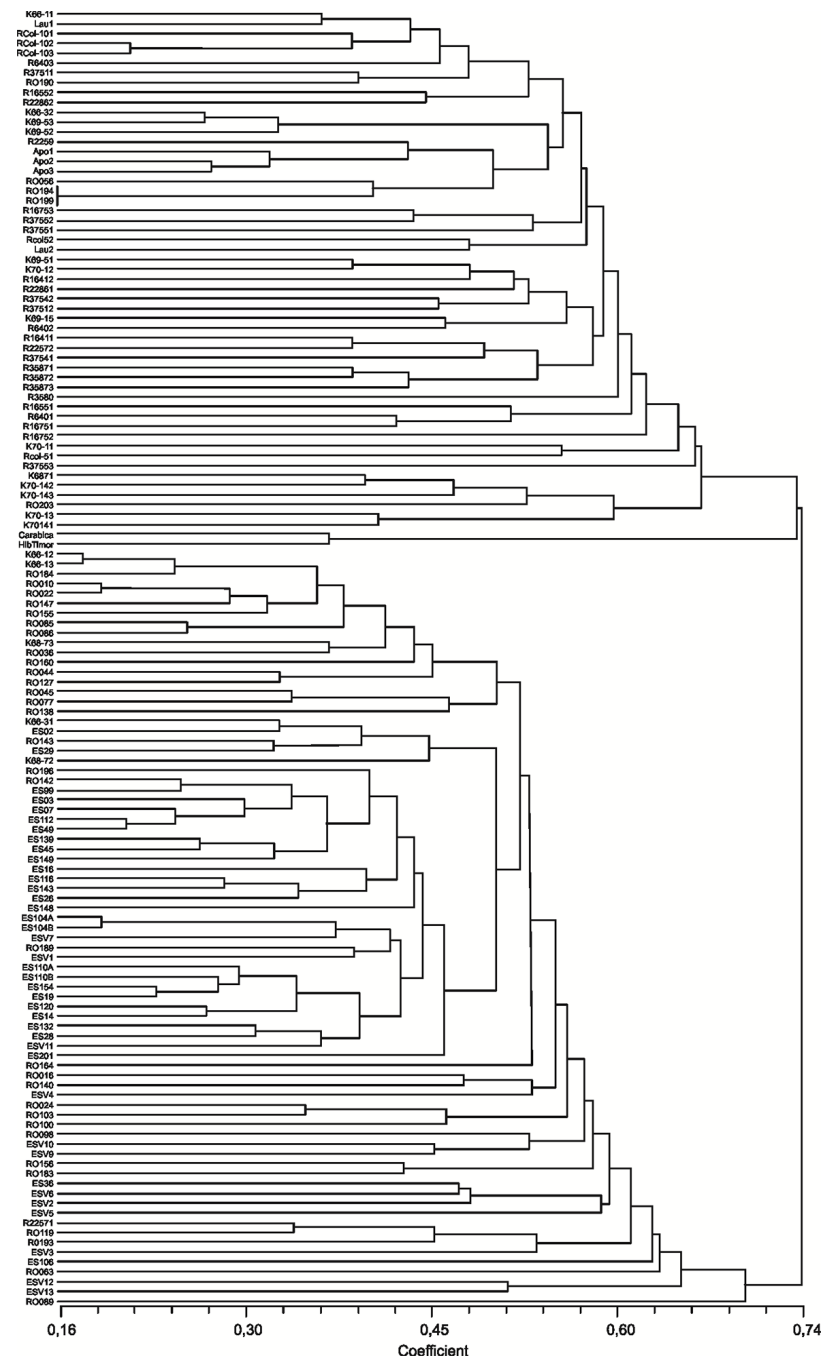

Figure 1. Dendrogram representing the dissimilarity among 130 Coffea canephora accessions, obtained by UPGMA method, based on the weighted coincidence index estimated over the polymorphism of 20 microsatellites

the accessions of IAC and UFV, which are composed by plants labeled as 'Kouillou' and 'Robusta'. Considering that only six, in a total of 73 accessions collected in plantations, share alleles with those genotypes, it is possible to infer the presence of that varietal group is still small in the most cultivated areas. Consequently, increasing the participation of that germplasm in Brazilian breeding programs would imply a lot of benefits. For instance, the use of Robusta alleles may promote the development of $C$. canephora clones highly resistant to leaf rust (Hemileia vastatrix Berk \& $\mathrm{Br}$.) and nematodes (Meloidogyne spp). Besides, those genotypes could aid to increase yield and improving beverage quality in new cultivars (Fazuoli et al. 2009, Souza and Santos

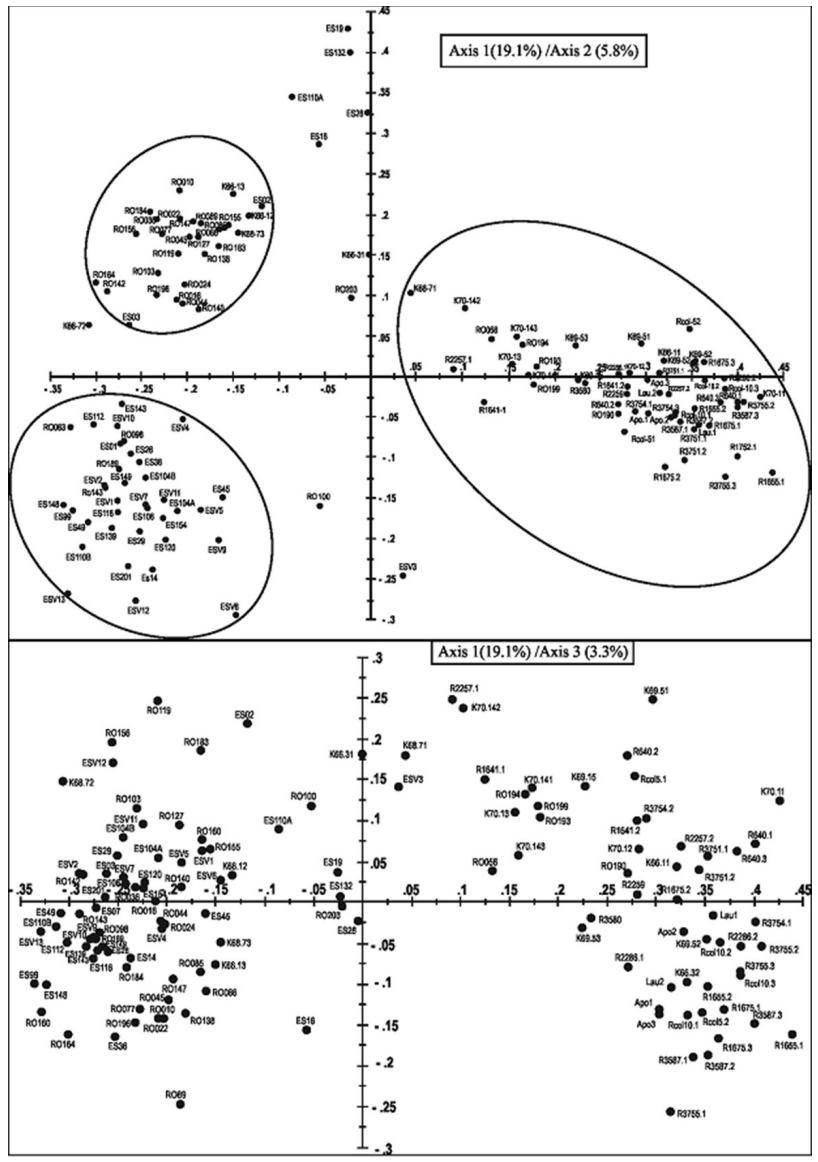

Figure 2. Principal coordinate analysis based on SSR data of 130 Coffea canephora accessions.

2009). Another aspect to be explored is the utilization of the heterosis resulting from intergroup crosses. Considering the genetic divergence observed between accessions of the varietal groups (Robusta and Kouillou) and the cultivated germplasm (clone from Rondônia and Espírito Santo), it is expected that their intercrosses may be advantageous. Similar strategy has been used for so long in some breeding programs around the world with remarkable success (Bouharmont et al. 1986, Leroy et al. 1997). Furthermore, 'Robusta' and 'Kouillou' are divergent heterotic groups with complementary characteristics. Robusta plants present high resistance to rust and nematodes, and give good beverage. On the other hand, Kouillou plants are tolerant to drought and they are easier to cultivate due to the smaller size. So, these populations compose a ideal combination to use in a reciprocal recurrent selection program, as it has been already performed in Ivory Cost, since 1984 (Leroy et al. 1993, Leroy et al. 1994, Leroy et al. 1997).

The set of new microsatellites performed a suitable molecular characterization and allowed assessing an im- 
FF Souza et al.

portant part of the diversity of C. canephora gene pool in Brazil. For the first time, representative samples of accessions from cultivated areas and germplasm collections were examined by microsatellites analysis. These markers revealed a high degree of polymorphism, which provided a satisfactory understanding of the genetic diversity among Coffea canephora accessions. Moreover, they allowed the proper grouping of different populations and varietal groups and showed to be able to resolve doubts about the accession classification. This is of great advantage, because the high intra-specific variability and the environmental effects can hinder the differentiation of populations or varietal groups based only on the phenotypic evaluation.

Despite the great polymorphism found in accessions came from areas under cultivation, the diversity may be increased. The present diversity has been enough to sup- port advances of Brazilian breeding programs, but a new threshold of genetic gains is expected with the intensification of the use of Robusta germplasm. Nowadays, Brazil plays a fundamental role in the C. canephora world production. Therefore, the establishment of new ways of germplasm interchanging with other collections around the world should be an important initiative to promote introduction of new accessions.

\section{ACKNOWLEDGEMENTS}

Authors thank to Brazilian Consortium for Coffee Research and Development (Consórcio Pesquisa Café), National Council of Scientific and Technological Development (CNPq), Fundação de Amparo à Pesquisa do Estado de Minas Gerais (FAPEMIG) and Agrofuturo/Embrapa for the financial support.

\section{Diversidade Molecular no germoplasma de Coffea canephora conservado e cultivado no Brasil}

Resumo - Este trabalho objetivou caracterizar acessos de C. canephora oriundos de cultivos comerciais e bancos de germoplasma brasileiros. Um total de 130 acessos das coleções do IAC (São Paulo), UFV (Minas Gerais) e coletados em plantios comerciais no Espírito Santo e Rondônia foram genotipados com 20 novos microssatélites. Métodos multivariados foram utilizados para estimar a relação entre os acessos. Foi observado alto nível de polimorfismo e dois grupos foram identificados: o primeiro foi constituído pelos genótipos conservados nas coleções de germoplasma do IAC e UFV e o segundo foi composto pelos acessos coletados em plantios comerciais. Os acessos do Espírito Santo e de Rondônia formaram dois subgrupos distintos. Apesar do grande polimorfismo encontrado nas lavouras brasileiras de café canéfora, incrementar essa diversidade é necessário, pois um novo limiar de ganhos genéticos é esperado nos programas de melhoramento com a intensificação do uso do germoplasma conservado.

Palavras-chave: Café robusta, diversidade genética, microssatélites.

\section{REFERENCES}

Bouharmont P, Lotodé R, Awemo J and Castaing X (1986) La sélection générative du caféier Robusta au Cameroun - Analyse des résultats d'un essai d'hybrides diallèle partiel implanté en 1973. Café Cacao Thé 30: 93-112.

Conab - Companhia Nacional de Abastecimento (2013) Acompanhamento da Safra Brasileira de Café - Safra 2012/2013. Brasília: Available at $<$ http://www.conab.gov.br/>. Accessed on 20 June, 2013.

Cruz CD (2001) Programa Genes (versão Windows): aplicativo computacional em genética e estatística. Editora UFV, Viçosa, 648p.

Diniz LEC, Sakiyama NS, Lashermes P, Caixeta ET, Oliveira ACB, Zambolim E, Loureiro ME, Pereira AA and Zambolim L (2005) Analysis of AFLP marker associated to the Mex-1 resistance locus in Icatu progenies. Crop Breeding and Applied Biotechnology 5: 387-393.

Fazuoli LC, Mistro JC and Braghini MT (2009) Melhoramento do café robusta no Instituto Agronomico de Campinas. In Zambolim L (Ed). Tecnologias para produção do café conilon. Editora UFV, Viçosa, p. 201-247.

Ferrão MAG, Ferrão RG, Fonseca AFA, Verdim Filho AC and Volpi
PS (2007a) Origem, dispersão, taxonomia e diversidade genética de Coffea canephora In Ferrão RG, Fonseca AFA, Bragança SM, Ferrão MAG and De Muner LH (eds.) Café conilon. Incaper, Vitória, p. 67-91.

Ferrão MAG, Fonseca AFA, Ferrão RG, Oliveira MA, Barbosa WM, D'isep MSP and Barbosa RP (2007b) Técnicas moleculares e biotecnológicas aplicadas ao café. In Ferrão RG, Fonseca AFA, Bragança SM, Ferrão MAG and De Muner LH (eds.) Café conilon. Incaper, Vitória, p. 175-201.

Fonseca AFA, Sediyama T, Cruz CD, Sakiyama NS, Ferrão MAG, Ferrão RG and Bragança SM (2006) Divergência genética em café conilon. Pesquisa Agropecuária Brasileira 41: 599-605.

Ivoglo MG, Fazuoli LC, Oliveira ACB, Gallo PB, Mistro JC, Silvarolla MB and Toma-Braghini M (2008) Divergência genética entre progênies de café robusta. Bragantia 67: 823-831.

Leroy T, Montagnon C, Charrier A and Eskes AB (1993) Reciprocal recurrent selection applied to Coffea canephora Pierre. I. Characterization and evaluation of breeding populations and values of intergroup hybrids. Euphytica 67: 113-125.

Leroy T, Montagnon C, Cilas C, Charrier A and Eskes AB (1994) Reciprocal recurrent selection applied to Coffea canephora Pierre. II. 
Estimation of genetic parameters. Euphytica 74: 121-128.

Leroy T, Montagnon C, Cilas C, Yapo A, Charmetant P and Eskes (1997) Reciprocal recurrent selection applied to Coffea canephora Pierre. III. Genetic gains and results of first intergroup crosses. Euphytica 95: $347-354$.

Maurin O, Davis PA, Chester M, Mvung EF, Jaufeerally-Fakim Y and Fay MF (2007) Towards a phylogeny for Coffea (Rubiaceae): Identifying well-supported lineages based on nuclear and plastid DNA sequences. Annals of Botany 100: 1565-1583.

Montagnon C, Leroy T and Eskes AB (1998) Amélioration variétale de Coffea canephora. I. Critères et méthodes de sélection. Plantations, Recherche, Développement 5: 18-28.

Perrier X, Flori A and Bonnot F (2003) Data analysis methods. In Genetic diversity of cultivated tropical plants. Science Publishers, Enfield, p. $43-76$.
Powell W, Machray GC and Provan J (1996) Polymorphism revealed by simple sequence repeats. Trends Plant Science 1: 215-222.

Rohlf FJ (1998) NTSYS-pc: numerical taxonomy and multivariate analysis system, version 2.1. Exeter Software, New York, 83p.

Silvestrini M, Maluf MP, Silvarolla MB, Guerreiro-Filho O, Medina-Filho HP, Vanini MMT, Oliveira AS, Gaspari-Pezzopane C and Fazuoli LC (2008) Genetic diversity of a Coffea germplasm collection assessed by RAPD markers. Genetic Resources and Crop Evolution 55: 901-910.

Souza FF and Santos MM (2009) Melhoramento genético do café canéfora em Rondônia. In Zambolim L (ed.) Tecnologias para produção do café conilon. Editora UFV, Viçosa, p. 175-200.

USDA - United States of American Department of Agriculture (2012) Coffee: world markets and trade. Washington, DC, 25p. (USDA. Foreign Agricultural Service. Circular Series). 